\title{
Towards Enhancing Service Delivery in Uganda’s Local Government Units: Is Fiscal Decentralization Still a Feasible Strategy?
}

Sudi Nangoli ${ }^{*}$, Mohammed Ngoma', Hassan Kimbugwe ${ }^{1}$ and Mayoka Kituyi ${ }^{2}$

${ }^{1}$ Department of Business Administration, Makerere University Business School, Kampala, Uganda

${ }^{2}$ Department of Business Computing, Makerere University Business School, Uganda

\begin{abstract}
The Ugandan government has for years depended on decentralization as a strategy for ensuring efficient delivery of services to its citizens. However, in the wake of obstacles like corruption, nepotism among others that have clouded fiscal decentralization, the need to re-examine its feasibility in explaining service delivery in Uganda's local governments has become apparent. This study thus examines the extent to which fiscal decentralization explains improvements in service delivery in Uganda's local government units. A quantitative survey research design was used in this study. Data were collected using a pretested questionnaire and analyzed using quantitative methods. Sampling was purposively done in three districts of Uganda and the respondents included Local Council members elected by local residents and the technical staff of the participating local governments. Correlation results revealed a positive and significant relationship between fiscal decentralization and service delivery $\left(r=.262^{* *}, p<.01\right)$ while regression results indicated that Fiscal Decentralization can predict Service delivery in local governments (Beta $=.452$, Sig. =.000). This study therefore recommended that despite the current inefficiencies in fiscal decentralization, it still stands out as a feasible strategy through which the quality of services provided by local governments can be enhanced. As such, the implementation of fiscal decentralization going forward, needs to be augmented with requisite policies to help in alleviating challenges like corruption, nepotism hence improving accountability and value for money on all government contracts sourced at local government levels. This will help improve on the quality of services provided by local governments.
\end{abstract}

Keywords: Fiscal decentralization; Local governments; Service delivery; Strategy; Uganda

\section{Introduction}

A number of existence studies reveal that fiscal decentralization as implemented in developing countries is meant to improve service delivery to the people while promoting government's developmental goals $[1,2]$. Fiscal decentralization a strategy for enhancing service delivery has to an extent achieved good results in many African countries such as Nigeria and Uganda [3,4]. Generally, governments usually decided to decentralize so as to facilitate political, economic, social, managerial, administrative and technical empowerment of local populations to fight poverty by empowering them to participating in planning and management of their development process $[1,5]$. In the case of Uganda, the country's powers to create local government units are clearly enshrined in its Constitution. Article 179 of the 1995 Uganda constitution allows the government through parliament to create new districts with financial autonomy in the interest of improved service delivery.

Notwithstanding the challenges, fiscal decentralization has been seen as an effective way of promoting service delivery, especially in rural areas. The 2006 report on Annual Assessment of Minimum Conditions and Performance Measures for Local Governments in Uganda indicated that many Ugandans agitate for the creation of new districts and other local council units with hope that there will be better service delivery [6,7]. However, on deeper analysis, empirical studies reveal that there is nothing much on ground to justify all the praises heaped on decentralization at large. In Uganda for instance, a number of the decentralized units do not have capacity to run themselves as evidenced by high failure rates of many of the newly created districts that averaged $50 \%$ in 1997 with minimum standards and $45.5 \%$ for districts created by financial year 2003/04 [8-10]. As a way of curbing some the obstacles to service delivery, concerned institutions like the Inspector General of Government (IGG) and other anticorruption watchdogs have interdicted and prosecuted some of the guilty local government officials on cases of financial misappropriation, corruption and abuse of office. For example, Lambright [11] reports that on April 6, 2001, the Chief Administrative Officer (CAO) of Kasese district in western Uganda was suspend from office over allegations of corruption, financial mismanagement and misappropriation of over Ush11M district funds and that the same scenario happened in Soroti district in eastern Uganda, where the Chief Finance Officer (CFO) and the District Development Program Officer were interdicted over misappropriation of over Ush17M district funds donated by the Netherlands to implement the district's development Projects. Considering these and many other factors such as corrupt council officials and lack of accountability [12], it is pertinent to revisit the feasibility of fiscal decentralization in improving delivery of services to the people. Thus the purpose of this study was to examine the feasibility of fiscal decentralization as a strategy for enhancing service delivery in Uganda's local governments.

The remaining sections in this paper present a review of the theoretical and empirical literature, the adopted methodology, presentation and discussion of findings, conclusions, recommendations and areas for further study

\section{Review of Theoretical and Empirical Literature}

This section presents a review of theoretical and empirical literature aligned to fiscal decentralization and service delivery in Local Government Units.

${ }^{*}$ Corresponding author: Sudi Nangoli, Department of Business Administration, Makerere University Business School, Kampala, Uganda, Tel: +256 4145059 21; E-mail: nangolisudi@gmail.com

Received March 16, 2015; Accepted April 27, 2015; Published May 03, 2015

Citation: Nangoli S, Ngoma M, Magoola IW, Kituyi M (2015) Towards Enhancing Service Delivery in Uganda's Local Government Units: Is Fiscal Decentralization Still a Feasible Strategy?. Int J Econ Manag Sci 4: 251. doi:10.4172/21626359.1000251

Copyright: $\odot 2015$ Nangoli S, et al. This is an open-access article distributed under the terms of the Creative Commons Attribution License, which permits unrestricted use, distribution, and reproduction in any medium, provided the original author and source are credited. 


\section{Theoretical underpinning of the study}

A number of theories have been adopted and adapted in studies relating Fiscal Decentralization and Service Delivery. According to Porcelli [13], these can largely be classified under the classical theory and second generation theories. The classical theories here include three related ideas, that is, Tiebout's model of local public good provision (Tiebout, [14-17], and Leviathan's model/hypothesis. The second generation theories include but are not limited to the Decentralization Theorem with political economy by Lockwood [18] and Decentralization in principal agent model of electoral accountability [13].

The applicability of the Tiebout model and the Decentralization Theorem in LDCs like Uganda, where corruption is common place, fail on grounds that benevolence is not always assured in dealings between central government and local government units as the theories in question advance. Although also prone to certain forms of corruption, the augmented ideas of the Leviathan hypothesis tend to provide a more plausible explanation of service delivery efficiency through fiscal decentralization. According to the Leviathan hypothesis, central governments operate like leviathans who in order to increase their control over the economy's resources, favour decentralization as a plausible approach of curtailing inefficiencies of central government yet maintain ultimate power $[13,17]$. This model as augmented by Lockwood [18] promotes efficiency using a political model were decision-making process is implemented via majority voting over alternative levels of public good provision rather than benevolence. It can therefore be hypothesized that Fiscal decentralization enhances service delivery even under conditions where delegates are corrupt.

\section{Conceptualization of key terms and Empirical review of the study concepts}

Decentralization which was started on the principles of self-control has of now proved to be a method of choice for bringing services closer to the people with its various forms as has been widely and successfully implemented in different countries. Decentralization is understood in different ways by different scholars who have come up with varying conceptual models and frameworks purporting to explain the same concept. To this end, a debate has been ignited to clearly understand the concept and practice of decentralization [19]. According Neyapti [20], Fiscal decentralization (FD) means devolution of power and responsibilities of national (central), government towards sub-national (local), governments. This study adopted the conceptualization by Oommen [21]. According to Oommen [21], decentralization means empowering the local people through empowering the local governments. In this breath, one key strand, called political decentralization is often referred to as the transfer of authority and political functions from central to local government based on the principles of equity and political representation in those local governments. In Uganda, local governments have a political wing manned by councilors who are locally elected on a balanced basis, which allows representatives from various political parties and socialcultural affiliations [22]. Stoop [23] further observes that genuine decentralization should engulf power struggles and promote the separation of power through devolution of power, in which resources and political decision making are "transferred to a separate lower tier of government". On the other hand, COMFREL [24] and Eriksen et al. [25] urge that democratic decentralization, in which local people use an elected legislative body to solve their own problems should encourage the participation of people in the decision making process and should promote access to important information on the way business is being run by a given local government. Eriksen et al. [25] and COMFREL [24] further urge that this kind of arrangement governments more responsive to the needs of locals through prioritization and proper resource planning and allocation.

According to scholars like Dziobek, Mangas and Kufa [1], the typical reason for fiscal decentralization in developing countries is to improve service delivery to the people while promoting government's developmental goals. This has to a certain extent achieved good results in some African countries such as Nigeria and Uganda [3,4]. The government of Rwanda decided to decentralize so that they facilitate political, economic, social, managerial, administrative and technical empowerment of local populations to fight poverty by empowering them to participating in planning and management of their development process [5]. Article 179 of the 1995 Uganda constitution allows the government through parliament to create new districts with financial autonomy in the interest of improved service delivery. Notwithstanding the challenges, fiscal decentralization has been seen as an effective way of promoting service delivery, especially in rural areas. That is why many Ugandans are agitating for the creation of new districts and other local council units with hope that there will be better service delivery [7]. However, on deeper analysis, one realizes that there is nothing much on ground to justify all the praises towards decentralization at large. For instance, most of these decentralized units do not have capacity to run themselves as evidenced by high failure rates of many of the newly created districts that averaged 50\% in 1997 with minimum standards and $45.5 \%$ for districts created by financial year 2003/04 [8-10]. Consideration this and many other factors such as corrupt council officials and lack of accountability [12], it is only logical for one to conclude that fiscal decentralization has failed to deliver services to the people.

\section{Methodology}

This section looks at the research methods used in the study.

\section{Research design}

A quantitative survey research design was used in this study. Data were collected using a pretested questionnaire and analyzed using quantitative methods.

\section{Sample design}

A sample of 600 respondents was picked purposively from three districts in Uganda. Two districts came from Eastern Uganda and one from Central. These include Mbale, Manafwa from East and Kampala from Central Uganda. In order to ensure well balanced opinions, one of the districts (Manafwa) was rural and one (Mbale) was urban. Kampala district was included because it is the capital city of Uganda and hosts most of the government ministries and the national parliament. At total of 250 respondents came from Mbale, 250 from Kampala and 100 respondents came from Manafwa. These numbers were based on the population density of the participating districts such that the urban districts contributed more respondents whereas a rural district with few residents contributed less.

The type of officials involved in study was Local Council members commonly referred to as LCs who are elected by local residents. These included L III (operating at sub county level), LC IV (operating at county level) and LC V (operating at district level). In addition to the council members, technical staffs of the selected local governments were also involved on the study. These included Chief Administrative Officers, 
Citation: Nangoli S, Ngoma M, Magoola IW, Kituyi M (2015) Towards Enhancing Service Delivery in Uganda's Local Government Units: Is Fiscal Decentralization Still a Feasible Strategy?. Int J Econ Manag Sci 4: 251. doi:10.4172/21626359.1000251

Page 3 of 5

the Sub-County Chiefs, Town Clerks and Assistant Town Clerks, Accountants, Revenue Collection Officers, Community Development Officers, Health Officers, Education Officers among others.

\section{Data analysis}

The data collected was coded and entered into SPSS software for analysis using quantitative methods i.e. descriptive statistics, correlations and regressions.

\section{Findings}

This section presents the findings from primary data.

\section{Validation of research instrument}

Cronbach Alpha Coefficient (CAC) and Content Validity Index (CVI) were used to test for the reliability and validity of the questionnaire respectively. The results in Table 1 below were generated for CAC and CVI: Cronbach Alpha Coefficient and Content Validity Index results in Table 1 above indicate that the questionnaire was valid and reliable since all variables scored CAC and CVI greater than 5 .

\section{Participation in revenue planning}

Descriptive statistics were also used to determine whether the respondents had ever participated in revenue planning committees and/or meetings in their respective local units. The results were analyzed based on yes or no responses as seen in Table 2 .

Results in Table 2 above indicate that majority respondents constituting 59.3 had never participated in revenue planning meetings and/or committees in their local units. On the other hand, 181 respondents constituting 40.7 had ever participated in revenue planning meetings and/or committees.

\section{Planning role}

Descriptive statistics including frequencies and percentages were also used to determine the role played by respondents in revenue planning meetings and/or committees in their respective local units. The results were analyzed as seen in Table 3.

Results in Table 3 above show that most respondents played the role of providing accounting services (freq $=125$ ). 95 respondent constituting $21.3 \%$ played the role of providing health services while 85 respondents representing $19.1 \%$ provided general administrative services. 75 respondents, representing $16.9 \%$ provided education services, while 31 contributing $7 \%$ played the role of providing environmental services. 29 respondents representing $6.5 \%$ played the role of providing physical and infrastructural services. Only 5 respondents representing $1.1 \%$ provided consultancy services in revenue planning committees.

\section{Fiscal decentralization and service delivery}

Descriptive statistics including means were used to determine whether and how fiscal decentralization improved service delivery in local councils. The results were analyzed as seen in Table 4 below.

Results in Table 4 above show that respondents strongly agreed that fiscal decentralization brought services nearer to the people (Mean=4.43), it was easy to get feedback from the community (Mean=4.44), and that there was better monitoring of government programmes (Mean=4.45). The respondents further agreed that fiscal decentralization made people to understand government priorities better $($ Mean=3.32).
The respondents however strongly disagreed that there was better quality work done by contractors due to close monitoring (Mean=2.21), there was reduced bureaucracy (Mean=2.43), there was better accountability (Mean=2.42) and also that there was value for money spent on government contracts (Mean=2.25).

\section{Correlation for fiscal decentralization and service delivery}

Correlation analysis method was used to examine the relationship between fiscal decentralization and service delivery. Table 5 presents the correlation results:

Correlation results in Table 5 above reveal that there is a positive and significant relationship between fiscal decentralization and service delivery $\left(\mathrm{r}=.262^{* *}, \mathrm{p}<.01\right)$.

\section{Regression analysis}

In determining the power of fiscal decentralization in improving service delivery, regression analysis was used. The results are shown in Table 6.

Regression results seen in Table 6 above show that Fiscal Decentralization can predict Service delivery in local governments $($ Beta $=.452)$. The regression model is valid given that Sig. $=.000$.

\section{Discussion of Findings}

This section presents a discussion of findings aimed at addressing the question 'To what extent has fiscal decentralization strategy helped achieve improved service delivery in Uganda Local Governments?' Correlation results revealed a positive and significant relationship between fiscal decentralization and service delivery. The regression of the two variables was also significant with a standardized coefficient of (0.452). These findings not only mean that enhancement in service delivery in local governments are positively related to improvements in fiscal decentralization, but that changes in fiscal decentralization

\begin{tabular}{|c|c|c|c|c|}
\hline Variable & N of point & Anchor & CAC & CVI \\
\hline Fiscal Decentralization & 7 & 5 point & 0.605 & 0.613 \\
\hline Service Delivery & 8 & 5 point & 0.674 & 0.653 \\
\hline
\end{tabular}

Table 1: Validity and reliability tests.

\begin{tabular}{|c|c|c|c|c|}
\hline $\begin{array}{c}\text { Have you ever participated } \\
\text { in revenue planning? }\end{array}$ & $\mathbf{F}$ & $\%$ & Valid Percent & $\begin{array}{c}\text { Cumulative } \\
\text { Percent }\end{array}$ \\
\hline Yes & 181 & 40.7 & 40.7 & 40.7 \\
\hline No & 264 & 59.3 & 59.3 & 100.0 \\
\hline Total & 445 & 100.0 & 100.0 & \\
\hline
\end{tabular}

Source: Primary Data

Table 2: Participation in revenue planning.

\begin{tabular}{|l|c|c|c|c|}
\hline Role/service & F & $\%$ & Valid Percent & $\begin{array}{c}\text { Cumulative } \\
\text { Percent }\end{array}$ \\
\hline Accounting Services & 125 & 28.1 & 28.1 & 28.1 \\
\hline Education Services & 75 & 16.9 & 16.9 & 44.9 \\
\hline Health Services & 95 & 21.3 & 21.3 & 66.3 \\
\hline General Administration & 85 & 19.1 & 19.1 & 85.4 \\
\hline Physical Infrastructure & 29 & 6.5 & 6.5 & 91.9 \\
\hline Environment & 31 & 7.0 & 7.0 & 98.9 \\
\hline Consultant & 5 & 1.1 & 1.1 & 100.0 \\
\hline Total & $\mathbf{4 4 5}$ & $\mathbf{1 0 0 . 0}$ & $\mathbf{1 0 0 . 0}$ & \\
\hline
\end{tabular}

Source: Primary Data

Table 3: Role played 


\begin{tabular}{|c|c|c|c|c|}
\hline \multicolumn{5}{|l|}{ Descriptive statistics } \\
\hline & $\mathbf{N}$ & Min & Max & Mean \\
\hline Services are brought nearer to the people & 445 & 1 & 5 & 4.43 \\
\hline People understand government priorities better & 445 & 1 & 5 & 3.32 \\
\hline It is easy to get feedback from the community & 445 & 1 & 5 & 4.44 \\
\hline There is better monitoring of government programmes & 445 & 1 & 5 & 4.45 \\
\hline $\begin{array}{l}\text { There is better quality work done by contractors due } \\
\text { to close } \\
\text { monitoring }\end{array}$ & 445 & 1 & 5 & 2.21 \\
\hline There is reduced bureaucracy & 445 & 1 & 5 & 2.43 \\
\hline There is better accountability & 445 & 1 & 5 & 2.42 \\
\hline $\begin{array}{l}\text { There is value for money spent on government } \\
\text { contracts }\end{array}$ & 445 & 1 & 5 & 2.25 \\
\hline
\end{tabular}

Source: Primary Data

Table 4: Service delivery.

\begin{tabular}{|r|c|c|c|}
\hline \multicolumn{2}{|c|}{} & $\begin{array}{c}\text { Fiscal } \\
\text { Decentralization }\end{array}$ & $\begin{array}{c}\text { Service } \\
\text { delivery }\end{array}$ \\
\hline \multirow{3}{*}{ Fiscal Decentralization } & Pearson Correlation & 1 & $.262^{* *}$ \\
\cline { 2 - 4 } & Sig. (2-tailed) & & .000 \\
\cline { 2 - 4 } & $\mathrm{N}$ & 442 & 442 \\
\hline \multirow{3}{*}{ Service delivery } & Pearson Correlation & $.262^{* *}$ & 1 \\
\cline { 2 - 4 } & Sig. (2-tailed) & .000 & \\
\cline { 2 - 4 } & $\mathrm{N}$ & 402 & 402 \\
\hline \multirow{2*}{*}{. Correlation is significant at the 0.01 level (2-tailed). } \\
\hline
\end{tabular}

Table 5: Correlation.

\begin{tabular}{|c|c|c|c|c|c|c|}
\hline & \multirow[t]{2}{*}{ Model } & \multicolumn{2}{|c|}{$\begin{array}{l}\text { Unstandardized } \\
\text { Coefficients }\end{array}$} & \multirow{2}{*}{\begin{tabular}{|l|} 
Standardized \\
Coefficients \\
Beta
\end{tabular}} & \multirow[t]{2}{*}{ t } & \multirow[t]{2}{*}{ Sig $^{a}$. } \\
\hline & & B & Std. Error & & & \\
\hline \multirow{2}{*}{1} & (Constant) & 1.97 & .029 & & 8.111 & .000 \\
\hline & Fiscal Decentralization & .431 & .043 & .452 & 6.024 & .000 \\
\hline
\end{tabular}

a. Dependent Variable: Service delivery

Table 6: Regression results.

can explain about $45.2 \%$ of the changes in service delivery. In the same breath, the findings on some particular questions asked indicated that fiscal decentralization helps to improve service delivery because it brings services nearer to the people and that it is easy to get feedback from the community. The findings also indicated that there was better monitoring of government programmes, people understand government priorities better with fiscal decentralization. These findings are in line with literature. For example Akinyele [3] and Malesky [4]; Republic of Rwanda policy report [5], Republic of Uganda [7] all argued for the same points. The findings however contradicted with some literature on the suggestion that fiscal decentralization brought about better quality work done by contractors, reduced bureaucracy, improved accountability and also that there was value for money spent on government contracts. The findings pointed out corruption and nepotism as key hindrances towards the success of fiscal decentralization. The findings further indicated that there was too much political interference in the running of work, that councilors were not well educated and knowledgeable about government programmes and also that there was poor pay for technical staff. The findings further indicated that paying councilors allowances and other emoluments was too costly for local governments hence hindering service delivery. In addition, the findings indicated that local governments did not have adequate sources of revenue necessary for delivering services to the people.

\section{Conclusion, Recommendations and Areas for Further Study}

Considering the literature, findings and the discussion of the findings, it can be concluded that fiscal decentralization is still a feasible strategy for bringing about improved service delivery in local governments. It can also be concluded that fiscal decentralization most times fails to bring about better quality services because most contractors hired to provide services on behalf of government are compromised through corruption and other tendencies such as nepotism, favoritism and abnormal bureaucracies. There is was a problem of accountability and no value for money spent on government contracts. Hence, this study recommends that fiscal decentralization should be implemented along with other policies to help monitor for corruption, nepotism, accountability and value for money on all government contracts sourced at local government levels. This will help improve on the quality of services provided by local governments. The local communities should also be directly involved in evaluating the works of contractors to ensure there is value for money. In schools for example, parents can form associations that monitors the performance of teachers. The same can be done in government hospitals and health centers run by local governments such that government employees provided better services. Village communities can also form committees for monitoring government contracts in their areas of jurisdiction. For instance a village committee can monitor the monitors of services provided on borehole and report directly to the relevant authorities such as the Inspector of Government and Anti-corruption courts where a contractor has delivered poor quality services. Further studies in this area should address a bigger sample to give a reflection of the possible changes in the predictive power of the independent variable.

\section{References}

1. Dziobek C, Mangas CG, Kufa P (2011) Measuring Fiscal Decentralization Exploring the IMF's Databases. International Monetary Fund.

2. Jutting J, Corsi E, Kauffmann C, Mcdonnell I, Osterrieder H, et al. (2005) What Makes Decentralisation in Developing Countries Pro-poor? The European Journal of Development Research 17: 626-648.

3. Akinyele RT (1996) States Creation in Nigeria: The Willink Report in Retrospect. African Studies Review 39: 71-94.

4. Malesky E (2005) Gerrymandering - Vietnamese Style: The Political Motivations behind the Creation of New Provinces in Vietnam. Paper presented at the Midwest Political Science Association 63rd Annual Conference. Measures for Local Governments, 2003. The Republic of Uganda

5. Republic of Rwanda policy Report (2000) Implementation strategy for National Decentralization Policy. Ministry of Local Government and Social Affairs, Republic of Rwanda.

6. Oguttu W, Opondo O (2007) What are the Implications of Creating More Districts? New Vision.

7. Republic of Uganda (2007) Annual Assessment of Minimum Conditions and Performance Measures for Local Governments, 2006. The Republic of Uganda

8. Tumushabe G, Mushemeza EG, Tamale LM, Lukwago D, Ssemakula E (2010) Monitoring and Assessing the Performance of Local Government Councils in Uganda; Background, Methodology and Score Card. ACODE.

9. Buwembo J (2005) What's the Fuss about New Districts? The Monitor. Clegg Nick and Greg Clark (2010). Decentralisation and the Localism Bill: an essential guide. HM Government, ISBN: 9781409826620

10. Republic of Uganda (2004) Annual Assessment of Minimum Conditions and Performance

11. Lambright MSG (2010) Decentralization in Uganda: Explaining Successes and Failures in Local Governance. The Journal of Politics. 
Citation: Nangoli S, Ngoma M, Magoola IW, Kituyi M (2015) Towards Enhancing Service Delivery in Uganda's Local Government Units: Is Fiscal Decentralization Still a Feasible Strategy?. Int J Econ Manag Sci 4: 251. doi:10.4172/21626359.1000251

Page 5 of 5

12. Horng V, Pak Kimchoeun, Ann S, Ngo N (2005) Decentralization and Deconcentration Reforms in Cambodia: an Early Review', in K. Murshid and B. Ballard (eds) Annual Development Review, Phnom Penh. CDRI.

13. Porcelli $F$ (2009) Fiscal Decentralisation and efficiency of government. A brief literature review. Department of Economics - University of Warwick (UK) Downloaded on 16th march 2015.

14. Tiebout CM (1956) A pure theory of local expenditures. The Journal of Political Economy 64: 416-424.

15. Oates WE (1985) Searching for leviathan: An empirical study. America Economic Review 75: 748-757.

16. Oates W E (1999) An essay on fiscal federalism. Journal of Economic Literature 27: $1120-1149$

17. Brennan D, Buchanan J (1980) The Power to Tax: Analytical Foundations of a Fiscal Consitution. Cambridge University Press, Cambridge.

18. Lockwood B (2007) Voting, lobbying, and the decentralization theorem Economics and Politics 20: 416-431.
19. Yuliani EL (2004) Decentralization, deconcentration and devolution: what do they mean? Interlaken Workshop on Decentralization

20. Neyapti B (2005) Equalization via Fiscal Decentralization.

21. Oommen MA (2008) Fiscal Decentralisation to Local Governments in India. Cambridge Scholars Publishing, Newcastle, UK.

22. Rondinelli (1999) A Review of Literature of Decentralization. UNDP New York.

23. Stoop (2002) Sited by COMFREL (2007) Assessment of the First Term of Decentralization in Cambodia, 2002-2007. COMFREL.

24. COMFREL (2007) Assessment of the first term of decentralization Decentralization in Cambodia. Commune Council Performance and Citizens Participation, 2002-2007.

25. Eriksen (1999) Sited by COMFREL (2007) Assessment of the First Term of Decentralization in Cambodia, 2002-2007. 